\title{
Implementasi Model STEMPROCSI Studi Kasus Pada Program Studi Pendidikan Teknik Informatika dan Komputer Di Universitas Bung Hatta
}

\author{
Karmila Suryani ${ }^{1^{*}}$ dan Khairudin ${ }^{2}$ \\ ${ }^{1}$ Program Studi Pendidikan Teknik Informatika dan Komputer, Universitas Bung Hatta \\ ${ }^{2}$ Program Studi Pendidikan Matematika, Universitas Bung Hatta, Padang \\ ${ }^{*}$ Corresponding author, e-mail: karmila.suryani@bunghatta.ac.id
}

\begin{abstract}
Abstrak- Penelitian ini menyajikan implementasi model STEMProcsi yang bertujuan untuk 1) mengetahui pemahaman mahasiswa tentang pembelajaran Science, Technology, Engineering, and Mathemetic, Projek dan Simulasi (STEMProcSi). 2) untuk mengukur keterampilan mahasiswa dalam menggunakan komponen-komponen STEMProcsi yang menghasilkan sebuah proyek, dan 3) Menilai sikap mahasiswa terhadap model pembelajaran STEMProcSi. Penelitian ini menggunakan sampel sebanyak 15 orang mahasiswa Pendidikan Teknik Informatika dan Komputer (PTIK) pada semester ganjil tahun akademik 2019/2020. Prosedur penelitian dilaksanakan dengan langkah; 1) memberikan permasalahan yang diselesaikan dengan peta konsep menggunakan aplikasi XMIND, 2) Penyelesaian perhitungan menggunakan aplikasi misrosoft Excel, dan 3) Membuat produk yang interaktif dengan aplikasi Scatch. Instrumen penelitain berupa kusioner menggunakan skala liker. Berdasarkan analisa data maka hasil penelitian ini menunjukan bahwa dengan penerapan model STEMProcSi ini dapat menumbuhkan minat dan antusias mahasiswa dalam memahami materi, melatih berpikir krititis, kratif, komunikatif dan kolaboratif serta dapat menghasilkan sebuah produk interaktif. Hal ini terbukti dari perolehan nilai median untuk semua pertanyaan dengan nilai 4 yang nilainya lebih tinggi dari skor ratarata skala liker yaitu 3. Oleh karena itu dapat disimpulkan bahwa model STEMProcsi ini baik digunakan dalam proses pembelajaran untuk mata kuliah eksakta di perguruan tinggi.
\end{abstract}

\section{Kata Kunci : STEM, Model STEMProcSi, Kreatifitas}

\begin{abstract}
This study is an implementation of the STEMProcsi model that aims to 1) Knowing the students ' understanding of learning Science, Technology, Engineering, and Mathemetic, Projects and Simulation (STEMProcSi). 2) to measure student skills in using the STEMProcsi components that produce a project, and 3) Assessing students' attitudes towards the STEMProcSi learning model. This research used 15 students as sample of Computer and Informatics Engineering Education (PTIK) in the odd semester of the academic year 2019/2020. The research procedure was carried out in trhee steps; 1) provides problems that are solved by concept maps using the XMIND application, 2) Complete calculations using the Microsoft Excel application, and 3) Create interactive products with the Scatch application. The research instrument uses a questionnaire with 5 liker scale. Based on data analysis, the results of this study indicate that the application of the STEMProcSi model can generate interest and enthusiasm of students in understanding the material, practice critical thinking, creative, communicative and collaborative and can produce an interactive product. Therefore it can be concluded that the STEMProcsi model is good to be used in the learning process for exact subject courses in tertiary institutions.
\end{abstract}

Keywords : STEM, Model STEMProcSi, Creativity

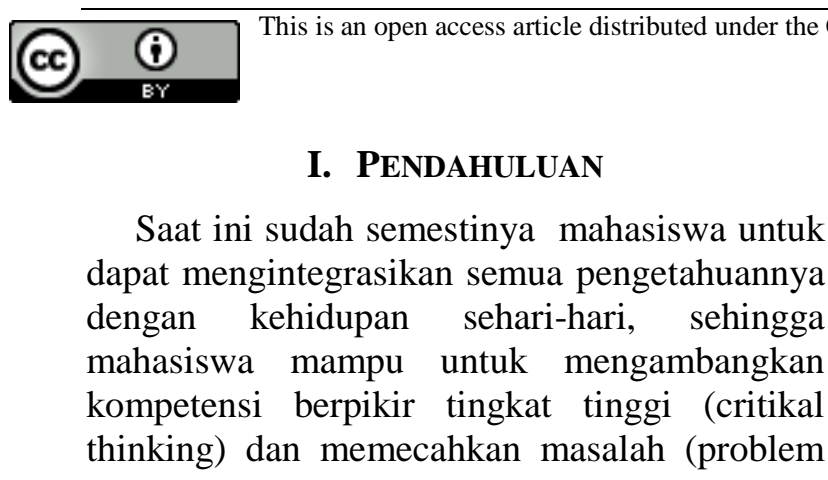

solving) dengan baik. Menurut [1] pada era revolusi industri 4.0 akan dikembangkan pada 3 bidang utama diantaranya Digital, Bioteknologi dan Fisika. Dalam rangka membantu mahasiswa untuk dapat melakukan proses berfikir kritis maka dilakukan dengan cara menerapkan berbagai model pembelajaran. 
Salah satu model pembelajaran yang tepat digunakan adalah model STEM.

Pendidikan di era industri 4.0 dengan model STEM semakin menarik minat dan perhatian pendidik di seluruh dunia. The National Science Teachers Association (NSTA), didirikan pada tahun 1944, pertama kali mendefinisi pendidikan STEM adalah pendekatan interdisipliner pembelajaran akademik yang memuat konsep penggabungan persoalan dunia nyata yaitu mahasiswa dapat menerapkan konteks Sains, Teknologi, Teknik dan Matematika yang menghubungkan antara sekolah, komunitas, pekerjaan dan perusahaan global untuk memungkinkan pengembangan literasi STEM sehingga dapat bersaing dalam ekonomi baru [2,3]. Selain itu [4,5] mengemukakan di masa sekarang dimungkinkan untuk menegosiasikan tantangan dan kontroversi dunia nyata menggunakan alat dunia nyata dalam konteks sosioteknik otentik

Karakteristik penting ketika berbicara tentang pendidikan STEM meliputi pendekatan interdisipliner, mengintegrasikan dengan pelajaran dunia nyata dan menghubungkan dari sekolah dan masyarakat untuk organisasi global. Melalui pendidikan STEM, mahasiswa mengembangkan keterampilan: pemecahan masalah, kreativitas, analisis kritis, pemikiran mandiri, kerjasama dalam tim, dan keterampilan komunikasi serta teknologi informasi. Menurut [6-8] dalam proses pembelajaran untuk mengimbangi pendidikan STEM ini dilakukan melalui model pembelajaran Problem-Based Learning (PBL) dimana mahasiswa dapat menemukan dan menyelesaikan masalah sendiri .

STEM merupakan singkatan dari Science, Techlonogy, Engineering dan Mathematics merupakan rancangan kegiatan pembelajaran yang langsung diaplikasikan ke dalam dunia nyata. [9] mengungkapkan bahwa model pembelajaran STEM adalah satu model yang sangat baik digunakan dalam proses pembelajaran. Dalam model pembelajaran STEM ini mahasiswa berperan aktif untuk menghasilkan sebuah produk baru dengan menerapkan teknologi yang ada sesuai dengan ilmu yang telah didapat. [10] mengungkapkan bahwa tujuan pembelajaran akan tercapai apabila menggunakan teknik instruksional yang menekankan pentingnya lingkungan belajar berpusat pada mahasiswa sehingga hasil belajar yang diperoleh mahasiswa menjadi lebih baik. Sejalan dengan itu [11] menjelaskan bahwa tidak ada perbedaan pembejaran STEM dengan pembelaran biasa namu prestasi belajar dalam pendidikan STEM mahasiswa perempuan lebih tinggi dibandingkan dengan mahasiswa lakilaki. sementara [12] mengungkapkan bahwa beberapa diantar pengajar di sekolah-sekolah lebih menyukai pembelajaran STEM karena mengkombinasikan antar pengetahuan dan teknologi.

Penerapan model STEM dalam pembelajaran telah menempeti posisi terpenting sehingga mahasiswa dapat dengan mudah untuk menguasai pengetahuan serta mengasah keterampilannya [13-19]. Menurut [20] Saat ini beberapa perguruan tinggi yang ada di sumatera belum menerapkan model pembelajaran STEM sehingga peneliti tertarik untuk melakukan eksperimen tentang model pembelajara STEM yang dikolaborasikan dengan metode proyek dan simulasi. Menurut [21] metode proyek dan simulasi sangat baik untuk digunakan dalam pengembangan berpikir kritis dan kreatif bagi mahasiswa di perguruan tinggi. Akhirnya, perguruan tinggi yang menerapkan pembelajaran STEM dapat mengembangkan strategi kerangka kerja kebijakan STEM secara nasional, memfasilitasi berbagai kegiatan yang dijalankan terpusat dan program berbiaya, termasuk reformasi kurikulum dan standar pengajaran baru; program universitas berkelas dunia, merekrut ahli asing bertalenta dan sistem program doktor baru; program dan inisiatif kolaboratif terdesentralisasi dan partisipasi dalam kegiatan STEM di sekolah-sekolah, pendidikan kejuruan dan sekolah tinggi yang berkaitn dengan industri, bisnis dan karir [22]. Sehingga model STEM ini dapat memenuhi persyaratan pembelajaran di Revolusi Industri 4.0 sehingga sangat bermakna untuk penelitian ini.

Pada tahun 2017, Arizona State University adalah Universitas nomor 1 di Amerika Serikat untuk pengembangan Inovasi, melalui USAID yang didanai oleh BUILD dalam program TI, sudah mulai mempromosikan pengembangan model inovatif di universitas-universitas ASEAN. Universitas Bung Hatta merupakan salah satu universitas yang terdapat di Indonesia tepatnya di Padang Sumatera Barat. Di Universitas Bung Hatta terdapat salah satu program studi yaitu Pendidikan Teknik Informatika dan Komputer (PTIK), dimana di Prodi PTIK ini telah menerapkan model pembelajaran berbasis STEMProcSi. Model ini menghubungkan empat bidang Sains, 
Teknologi, Teknik dan Matematika untuk menciptakan produk yang inovatif, dimana unsur teknologi secara khusus lebih ditekankan sebagai elemen pusat dari model. Selain itu model ini mengkombinasikan antara metode projek dan simulasi sehingga nantinya mahasiswa dapat menciptakan sebuah projek berupa simulasi. Model STEMProcSi diilustrasikan pada gambar 1.

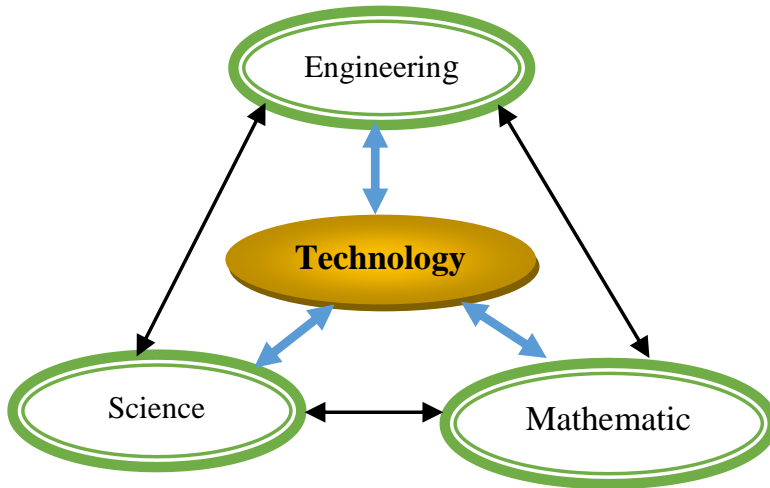

Gambar 1. Model STEMProcSi

Berdasarkan gambar 1 maka model STEMProcSi memiliki dua karakteristik dasar: (1) Mahasiswa mlakukan praktek dan pembuatan teknologi baru; (2) produk STEM dibuat oleh mahasiswa harus kreatif dan berdasarkan teknologi baru. Terknologi baru tersebut merupakan teknologi yang belum pernah digunakan oleh mahasiswa. Karakteristik dari model STEMProcSi ini dapat dilihat seperti gambar 2 .

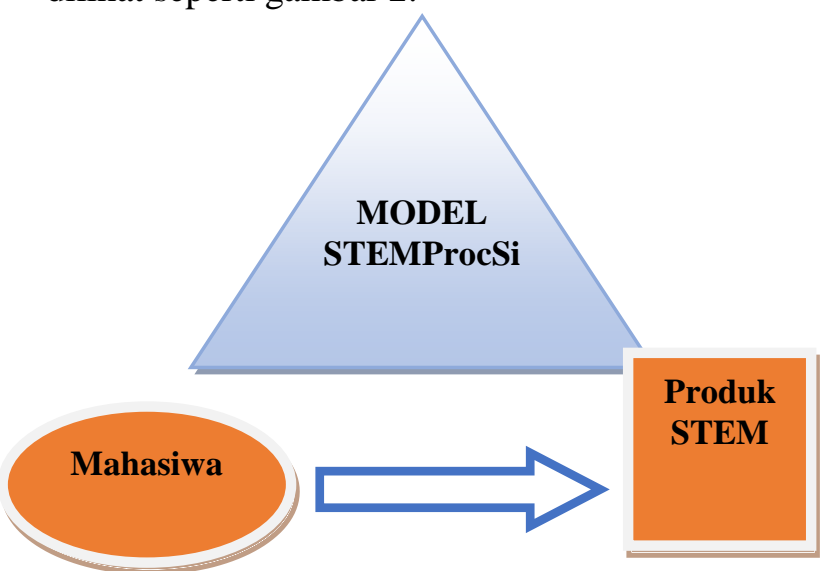

Gambar 2. Karakterisik Model STEMProSi

Berdasarkan gambar 2 terlihat bahwa target dalam model STEMProcSi ini adalah terciptanya sebuah produk yang dapat membangkitkan kreativitas mahasiswa dalam pembelajaran Sistem Operasi. Dalam peneltian ini ada tiga varibel yang diukur antara lain:
1. VP: variabel pengetahuan mahasiswa tentang model pambelajaran STEMProSi

2. VK: variabel keterampilan mahasiswa bagaimana menggunakan komponenkomponen STEMProcSi beserta jenis teknologinya.

3. VS: variabel sikap mahasiswa terhadap pembelajaran yang berlangsung ketika menggunakan model STEMProcSi

\section{METODA}

Penelitian ini menggunakan jenis penelitian eksperimen untuk mengimplementasikan model STEMProcSi pada mata kuliah sistem operasi. Populasi penelitian ini adalah seluruh mahasiswa PTIK di Universitas Bung Hatta yang mengambil mata kuliah sistem operasi. Sampel yang dipilih menggunakan Teknik total sapling dimana populasi menjadi sampel dengan jumlag mahasiswa sebanyak 15 orang.

Instrumen penelitian yang digunakan adalah mengadopsi dari penelitian [13] dengan penilaian sesuai skala liker.Teknik analisis data yang digunakan melalui survei terhadap mahasiswa dalam menilai hasil model STEMProcSi menggunakan 6 pertanyaan (dari Q1 ke Q7) yang bertujuan untuk mengevaluasi tiga jenis variabel yang telah ditetapkan. Variabel VP dievaluasi melalui pertanyaan Q1 dan Q2. Dalam pertanyaan Q1, terdapat tiga karakteristik dari pembelajaran STEM, sementara dalam pertanyaan Q2 mengandung lima ciri dari metode yang digunakan dalam model STEMProcSi

Sementara untuk variabel VK diamati dari hasil pertanyaan Q3 dan Q4, pertanyaan Q3 berkaitan dengan dua jenis produk STEMProcSi, untuk menilai keterampilan penciptaan produk dari mahasiswa masingmasing kelompok. Pertanyaan Q4 bertujuan untuk mengevaluasi tingkat penggunaan empat keterampilan dasar model STEMProcSi. Pertanyaan Q5 dan Q6 dirancang untuk mengevaluasi variabel VS, yang perlu dinilai adalah keuntungan dan kerugian dari model pembelajaran STEMProcSi serta tingkat penggunaan model ini bagi mahasiswa dimasa mendatang.

Adapun langkah-langkah yang dilakukan dalam penelitian ini adalah; 
1. Memberikan pembelajaran dengan model STEMProcSi dengan menggunakan beberapa teknologi yang terbaru,

2. Membagi mahasiswa menjadi beberapa kelompok dimana tiap kelompok terdiri dari 4 sampai 5 orang yang mempunyai kemampuan tinggi, sedang dan rendah. Setiap kelompok diberi kesempatan untuk mempersiapkan sebuah produk yang berhubungan dengan materi virtual memori.
3. Melakukan analisa terhadap kemampuan mahasiswa tentang model pembelajaran STEMProcSi yang telah dilaksanakan.

Adapun langkah-langkah implimentasi model sebagai berikut;

Langkah 1: Pengunaan program aplikasi XMIND untuk menganalisis kebutuhan permasalahan yang terjadi melalui alur-alur pemikiran yang menarik. Hasil dari peta pikiran dapat dilihat seperti gambar 3 .

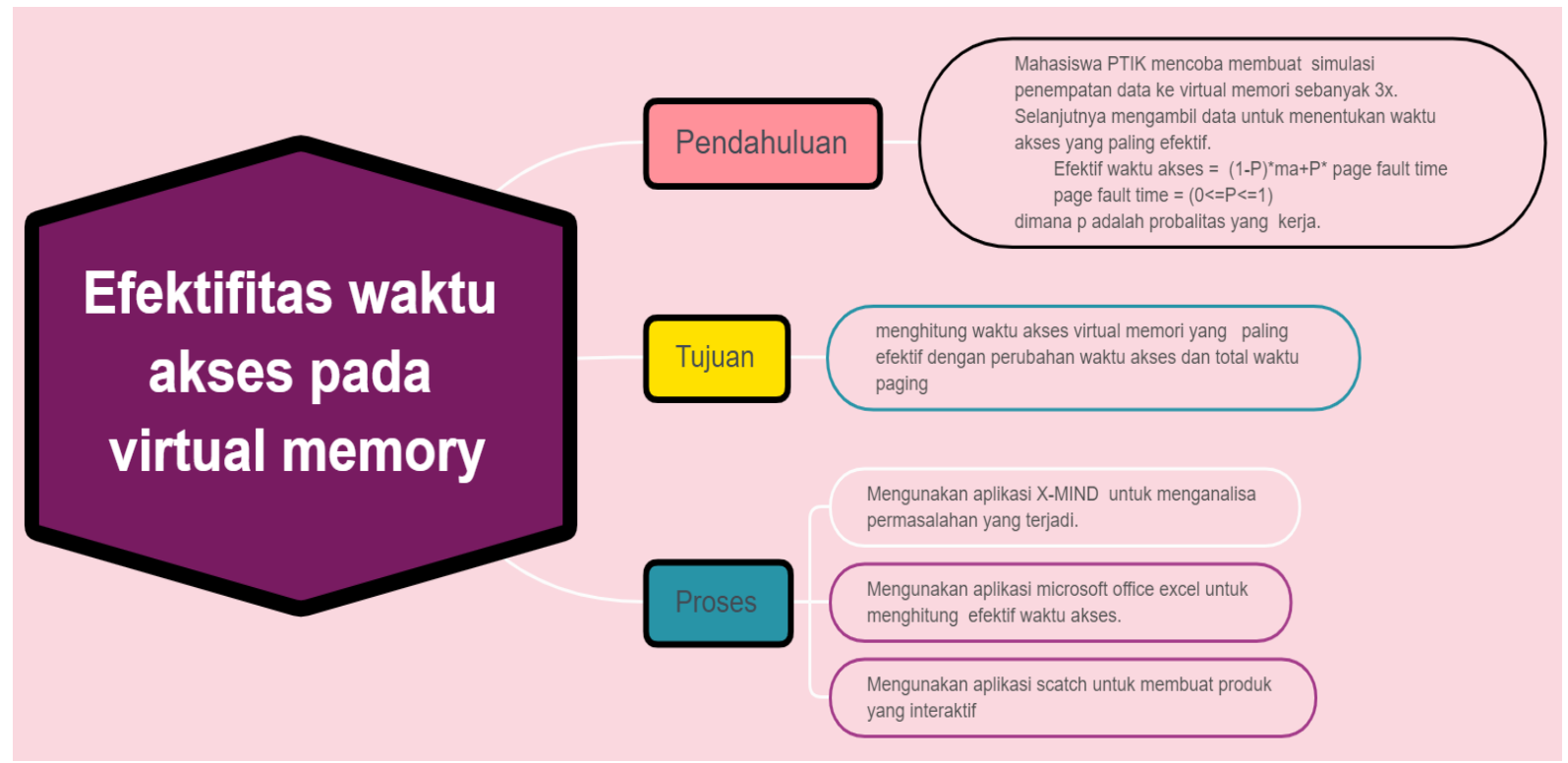

Gambar 3. Peta Konsep Pelaksanaan Model STEM Procsi,

Pada gambar 3 menguraikan tentang polapola pikiran yang dikembangkan dalam penyelesaian penelitain dengan menentukan pendahuluan, tujuan serta proses pelaksanaannya.

Langkah 2: Menggunakan program aplikasi microsoft office excel dalam menghitung afektivitas akses yang digunakan oleh memori oleh sistem. Sebelum menggunakan program ini maka terlebih dahulu mahasiswa mengetahui rumusnya secara manual yaitu;

$$
\text { Effective Access Time }=(1-\mathrm{p})^{*} \mathrm{ma} * \mathrm{~b} \text {, }
$$

dimana $p$ merupakan probaliltas dari akses data kedalam lokasi memori yang telah disediakan untuk masing-masing frame, ma merupakan waktu akses yang dibutuhkan untuk penempatan data setiap page dalam frame memori dan $b$ (page Fault time) merupakan total waktu paging dalam penempatan data. Untuk menetukan keefektifan waktu akses dari virtual memori ini maka terlebih dahulu dihitung probabilitasnya sesuai dengan rumus (1) maka diperoleh;

$$
\mathrm{p}=\mathrm{ma} /(\mathrm{ma}-\mathrm{b})
$$

(2),

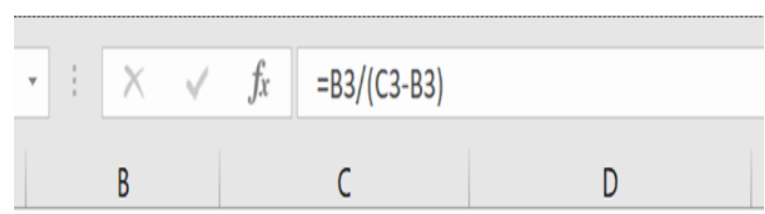

\begin{tabular}{|c|c|c|}
\hline $\begin{array}{c}\text { Waktu Akses } \\
\text { (ma) }\end{array}$ & Page Fault Time (b) & p \\
\hline
\end{tabular}

Gambar 4. Perhitungan Waktu Akses Memori mengunakan Microsoft Excel 
Gambar 4 memperlihatkan hasil dari probabilitas waktu akses penempatan data pada virtual memori secara tepat. Mahasiswa tidak perlu menghitung ulang untuk kasus berikutnya secara manual, mereka cukum melakukan klik drag pada hasil $\mathrm{p}$ maka hasilnya langsung muncul. Jadi dalam hal ini mereka dapat membuat keseimpulan nilai propabilitas yang baik diambil dalam penempatan data ke virtual memori. Setelah dilakukan simulasi menggunakan excel ini maka langkah selanjutnya menggunakan aplikasi scratch untuk membuat simulasi dengan animasi.

Langkah 3: Penggunaan aplikasi Scratch untuk membuat produk interaktif dan hasilnya seperti pada gambar 5 .

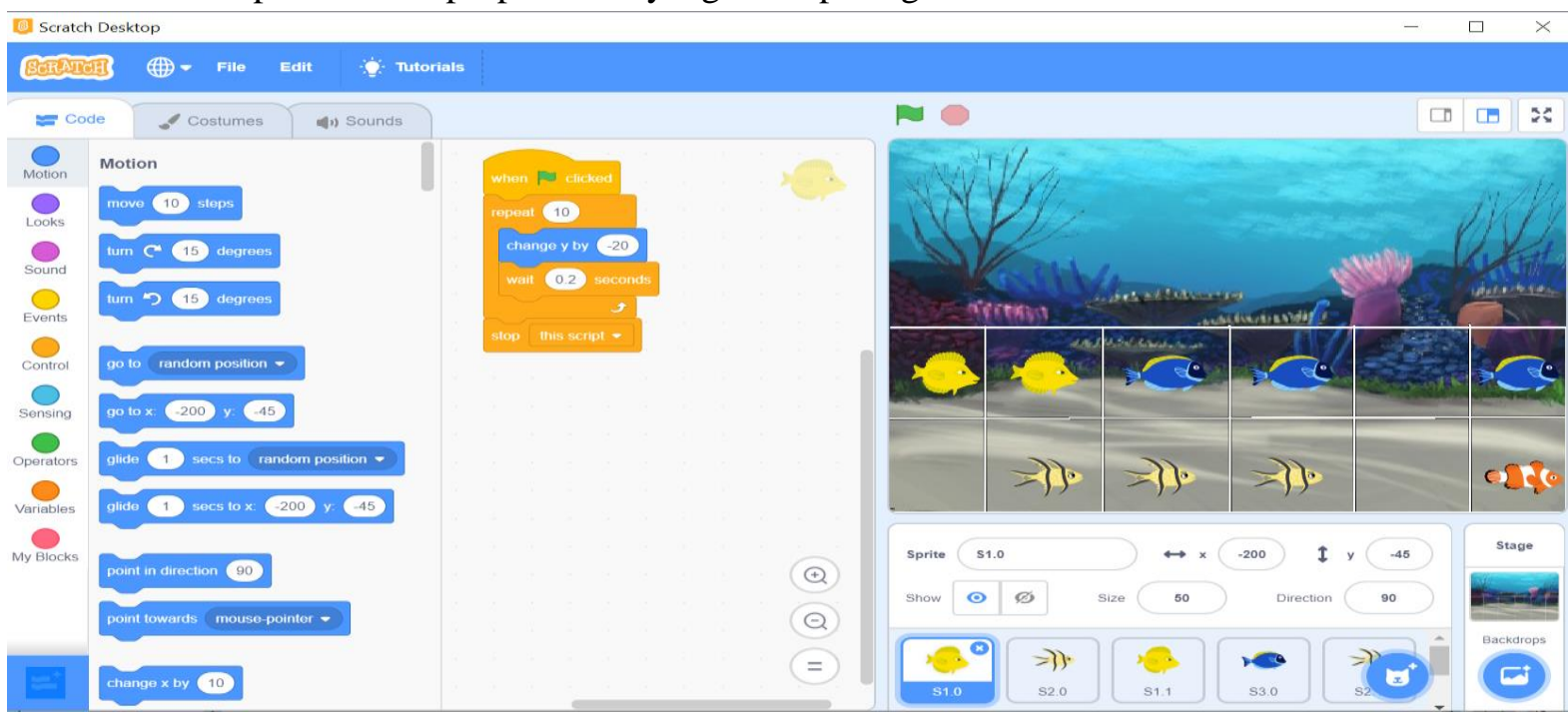

Gambar 5. Simulasi Penempatan Data dalam Virtuan Memory menggunakan Scratch

Gambar 5 terlihat proses penempatan data ke dalam page dengan menggunakan program alplikasi scratch. Data-data disimulasikan dengan jenis ikan yang berbeda-beda sehingga terlihat dengan jelas page mana yang tidak terisi sebagai page fault timenya. Program aplikasi scratch ini ketika dijalankan maka ikan-ikan yang berada di dalam akurium akan mergerak menempati page yang telah disiapkan sesuai dengan algoritma yang digunakan saat itu.

\section{HASIL DAN PEMBAHASAN}

Penelitian ini mengimplementasikan model STEMProcSi untuk menumbuhkan kreatifitas mahasiswa dalam pembelajaran serta melatih berpikir kritis dan kolaboratif. Mahasiswa diberikan suatu kasus tentang materi virtual memori kemudian mereka membuat sebuah proyek per kelompok. Proyek yang sudah diperoleh selanjutnya dipresentasikan di depan kelas. Hasil yang diperoleh dari kuisioner yang telah diisi oleh mahasiswa seperti tabel 1.

Pada tabel 1 menjelaskah rata-rata dan median dari perolehan skor kuisioner yang telah dibagikan. Untuk pertanyaan Q5 tidak dapat dilihat hasilnya berdasarkan nilai rata-rata dan median karena Q5 merupakan pertanyaan yang jawabanya memberikan pendapat tentang model pambelajaran STEMProcSi.

Tabel 1. Hasil Kuisioner secara Keseluruhan

\begin{tabular}{|c|c|c|c|}
\hline Pertanyaan & Responden (n) & Rata- & Median \\
\hline Q1A & 15 & 3,80 & 4 \\
\hline Q1B & 15 & 3,73 & 4 \\
\hline Q1C & 15 & 3,80 & 4 \\
\hline Q2A & 15 & 3,93 & 4 \\
\hline Q2B & 15 & 3,60 & 4 \\
\hline Q2C & 15 & 4,07 & 4 \\
\hline Q2D & 15 & 4,13 & 4 \\
\hline Q3A & 15 & 3,93 & 4 \\
\hline Q3B & 15 & 4,07 & 4 \\
\hline Q3C & 15 & 3,93 & 4 \\
\hline Q3D & 15 & 3,67 & 4 \\
\hline Q4A & 15 & 3,80 & 4 \\
\hline Q4B & 15 & 3,33 & 3 \\
\hline Q6 & 15 & 3,67 & 4 \\
\hline
\end{tabular}

Untuk melihat pentingnya hasil ini maka dilakukan analisa pada masing-masng subjeknya yang terlihat seperti gambar 6 . 


\section{Persentase Tingkat Pemahaman Pembelajaran STEM}

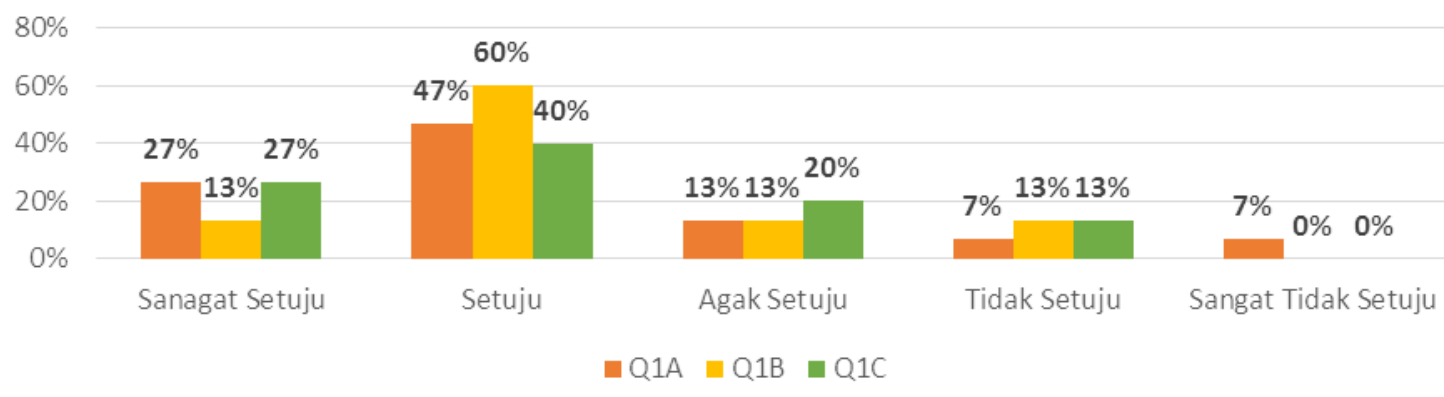

Gambar 6. Grafik Persentase Pemahaman Mahasiswa terhadap Pembelajaran STEM.

Berdasarkan gambar 6 terlihat bahwa pertanyaan Q1 lebih dominan memperoleh presentasi yang tinggi pada setujudan sangat setuju dan memperoleh nilai rata-rata 3,80 . Ini menunjukkan bahwa mahasiswa setuju dengan gagasan bahwa bahwa " Pembelajaran STEM dapat digunakan mahasiswa untuk menerapkan pengetahuan dan keterampilan dalam memecahkan masalah dengan praktek". Hal ini membuktikan bahwa dalam proses pembelajaran dengan menerapkan model STEMProcSi dapat membekali mahasiswa PTIK d era revolusi industri 4.0 terutama dalam memecahkan sebuah permasalahan melalui praktek. Dengan demikian setiap mahasiswa PTIK yakin dapat membangun rencana pelajaran untuk membantu mahasiswa menemukan hubungan antara mata pelajaran Sains, terutama Matematika dan Teknologi dengan kehidupan sehari-hari.

Untuk pertanyaan Q1B dengan rata-rata 3,7 menunjukkan bahwa mahasiswa setuju dengan ide " STEM berorientasi praktek dan penciptaan produk". Mahasiswa PTIK telah berhasil menciptakan sebuah produk berupa simulasi penempatan data dalam page kevirtual memory dan dapat diterapkan dalam diterapkan dalam kehidupan nyata selama pelajaran menggunakan model STEMProcSi. Pertanyaan Q1C memperoleh nilai rata-rata sebesar 3,8 hal ini menunjukkan bahwa mahasiswa setuju dengan gagasan "topik STEM bertujuan untuk berkomunikasi, bekerja sama (langsung atau tidak langsung) antara mahasiswa untuk mencapai tujuan bersama". Untuk menyelesaikan permasalahan dan produk dalam proses penhembangan dalam pembelajaran mahasiswa saling bekerja dan dapat meningkatkan komunikasi dan kerjasama.

Sementara nilai median yang diperoleh adalah 4 , dimana hasilnya lebih tinggi dari skala 3 (netral), menunjukkan bahwa pendapat mahasiswa untuk pertanyaan Q1 cenderung ke arah positif. Hal ini dapat diamati seperti gambar 7 yang memperlihatkan diagram segitiga, hal ini menunjukkan bahwa ketiga pilar dari pembelajaran STEM dianggap sama pentingnya oleh mahasiswa PTIK. Selain itu hasil dari Q1 ini menunjukan bahwa variabel pengetahuan (VP) yang berkaitan dengan pembelajaran STEM yang diterima dengan baik oleh mahasiswa. Selain itu diagram segitiga pada gambar 9 menunjukan tingkat keseragaman dalam pemanfaatan tiga pilar pembelajaan STEM.

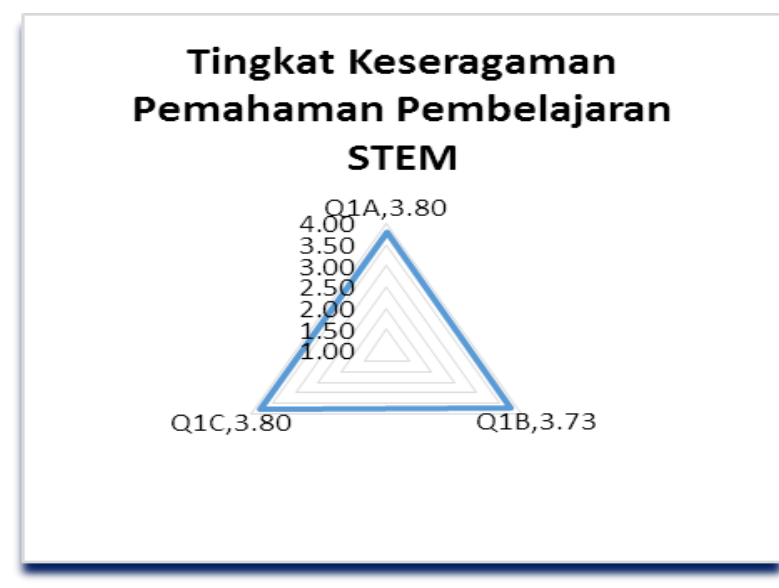

Gambar 7. Grafik Tingkat Keseragaman Pemahaman Pembelajaran STEM

Implementasi dari pembelajaran STEM dilakukan dengan model STEMProcSi yang hasil penelusuran seperti gambar 8 . 


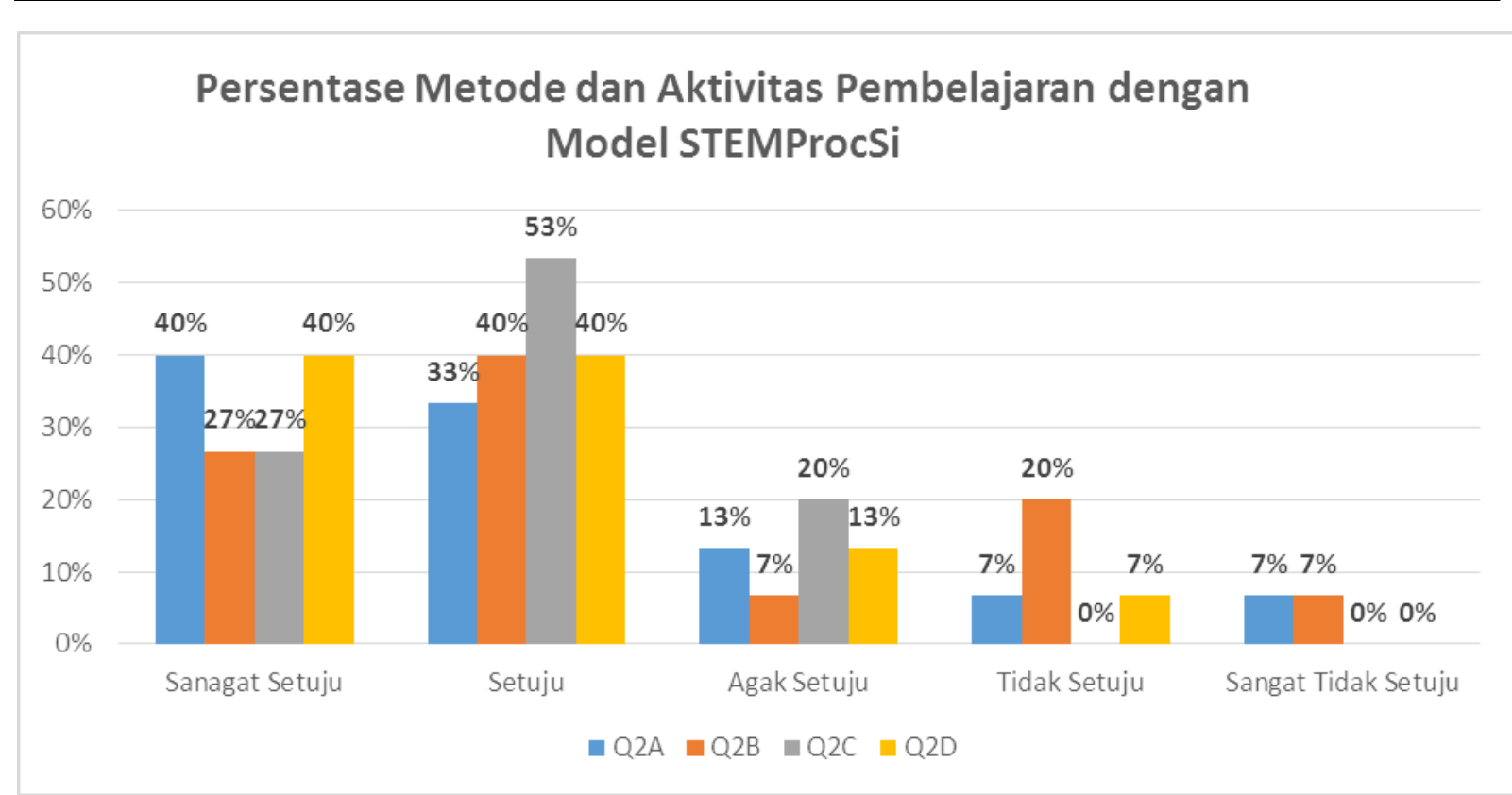

Gambar 8. Grafik Persentase Metode dan Aktivitas dengan Model STEMProcSi

Gambar 8 merupakan persentase metode dan aktivitas yang dilakukan dengan model STEMProcSi yang diperoleh dari tabel 5 untuk pertanyaan Q2A. Nilai rata-rata yang diperoleh sebesar 3,9, menunjukkan bahwa mahasiswa relatif setuju dengan ide " metode mengajar yang digunakan dengan model STEMProcSi ". Dengan demikian model ini dapat meningkatkan rasa percaya diri bagi mahasiswa dalam mengembangkan rencana pelajaran untuk menciptakan kondisi pembelajaran yang aktif dan kreatif. Untuk pertanyaa Q2B dengan nilai rata-rata 3,6 hal ini berati mahasiswa setuju dengan "metode mengajar dengan model STEMProcSi yang menggabungkan dan mengintegrasikan 4 bidang yaitu Sains, Teknologi, Teknik dan Matematika untuk menciptakan produk". Hasil tersenut menunjukkan bahwa mahasiswa tertarik dalam membangun rencana pengajaran terintegrasi dan dapat memenuhi persyaratan mengajar di era sekarang.

Sejalan dengan itu, pertanyaan Q2C juga menunjukkan persetujuan mahasiswa dengan "Kegiatan pembelajaran dengan model STEMProcSi dapat merangsang mahasiswa untuk berkomunikasi, bekerja sama dan mengembangkan pola berfikir kritis dan kreatif". Hal ini ditunjukan dengan perolehan nilai rata0rata untuk Q2C sebesar 4,1. Begitu juga dengan pertanyaan Q2D dengan perolehan nilai rata-rata 4,1 menandakan mahasiswa setuju dengan ide bahwa " Kegiatan mengajar dengan model STEMProcSi dapat menciptakan kegembiraan dan kekuatan bagi mahasiswa". Model STEMProcSi ini dapat menumbuhkan daya tarik dan semangat mahasiswa dalam proses pembelajaran. Dengan demikian, setiap mahasiswa mencoba untuk menumbuhkan keterampilan yang dibutuhkan dalam menyelesaikan sebuah permasalahan, khususnya teknologi informasi untuk memperbaiki dan meningkatkan daya tarik dari proses pelajaran.

Untuk megukur variabel pengetahuan yang dilihat dari perolehan nilai median untuk pertanyaan Q2 adalah 4, nilai ini lebih tinggi dari nilai rata-rata skor pada skala liker yaitu 3, menunjukkan bahwa pendapat mahasiswa terhadap model STMProcSi untuk VP cenderung ke arah positif, seperti terlihat pada gambar 9.

\section{Tingkat Sebaran Penggunaan Model STEMProcSi}

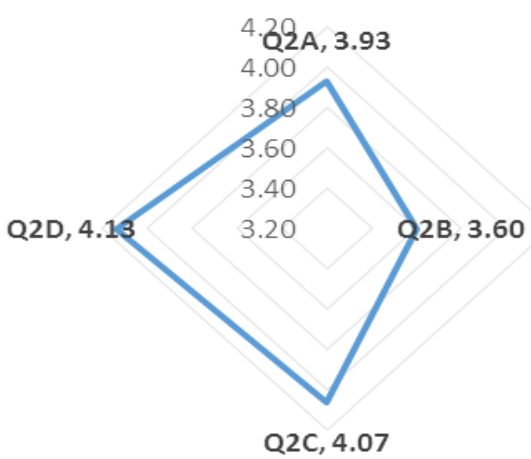

Gambar.9. Grafik Sebaran Penggunaak Model STEMProcSi 
Secara umum, dari penilaian metode pengajaran yang digunakan dalam pembelajaran STEM, variabel VP memiliki nilai lebih tinggi dari nilai rata-rata scor skala liker dan cenderung ke arah positif. Nilai-nilai kuantitatif untuk empat metode dalam model STEMProcSi inilainya lebih kurang sama dan mirip dengan hasil di pertanyaan Q1. Hal ini menunjukkan bahwa dalam pelaksanaan pembelajaran dengan menggunakan STEMProcsi dapai meningkatkan rasa percaya diri dan komunikasi mahasiswa untuk menghasilkan sebuah produk.
Singkatnya, dalam pertanyaan Q3 ini, variabel yang diukur di sini adalah variabel keterampilan VK terkait dengan kemampuan mahasiswa untuk menciptakan produk dalam model STEMProcSi. Hasil penelitian menunjukkan bahwa nilai VK memperoleh rata-rata lebih dari 3. Hal ini membuktikan bahwa menciptakan produk STEM bagi mahasiswa dalam model STEMProcSi berjalan dengan baik dan lancar, seperti pada gambar 10.

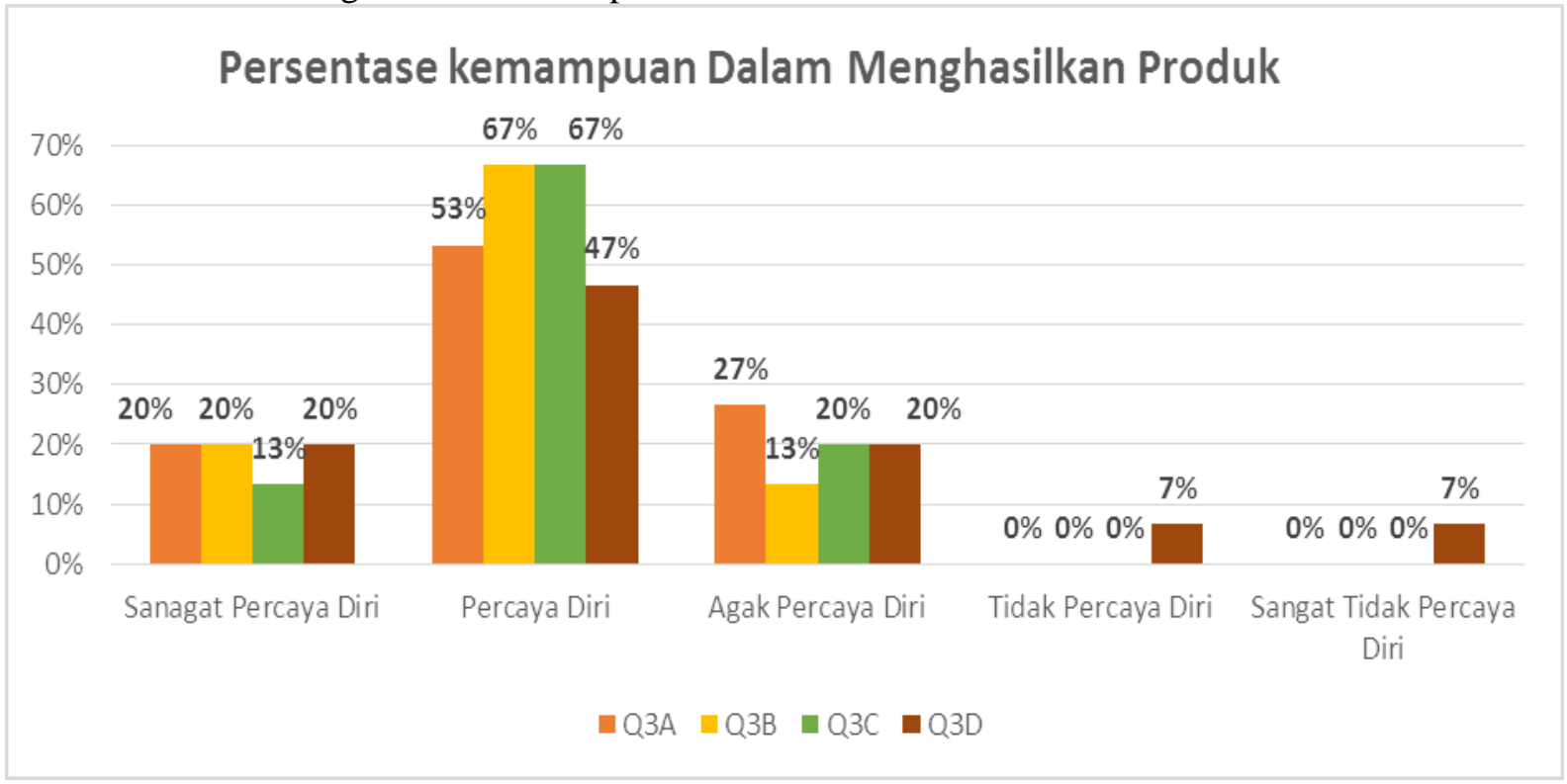

Gambar 10. Grafik Kemampuan Dalam menghasilkan Produk

Gambar 10 menjelaskan tentang kemampuan keterampilan mahasiswa dalam mengimplementasikan 4 keterampilan STEM. Rata-rata dalam persentase perolehan nilai berada pada kategori "percaya diri", namun masih ada diantara mahasiswa yang merasa masih "agak percaya diri" dan berada pada nilai rata-rata 3 pada skala liker. Untuk penguasaan komponen teknik dan teknologi mahasiswa memperoleh nilai $67 \%$, hal ini membuktikan bahwa mahasiswa PTIK memiliki kemampuan yang lebih tinggi di bidang ini dibandingkan dengan komponen sain dan matematika. Ada $20 \%$ diantara mahasiswa yang sudah memiliki rasa "sangat percaya diri" dalam penguasaan keterampilan bidang teknologi. Selain itu untuk mengukur keterampilan mahasiswa dalam penggunaan program aplikasi yang digunakan dalam model STEMProcSi ini terlihat seperti gambar 11.

Berdasartkan tabel 1 terlihat bahwa ratarata perolehan nilai untuk pertanyaan Q4A dan QQB adalah 3,8 dan 3,3, masing-masing nilai ini menunjukkan bahwa mahasiswa PTIK telah dapat dengan mudah dalam menggunkan program aplikasi Scratch dalam model STEMProcSi. Hal ini juga ditunjukan oleh gambar 11 , terlihat $53 \%$ dari mahasiswa menyatakan program aplikasi Sratch ini mudah untuk dipelajari dan digunakan. Namun untuk penggunaan program aplikasi Excel masih ada mahasiswa yang agak sulit untuk menggunakanya, hal ini dikarenakan penulisan rumus dalam excel yang membutuhkan analisa yang tinggi. Perolehan nilai median dari pertanyaan Q4B ini juga beraada pada nilai rata-rata pada skala liker yaitu 3. Dalam hal ini perlu adanya tambahan waktu untuk penggunaan aplikasi excel terutama untuk menuankan rumus matematika secara manual kedalam program aplikasi.

Selanjutnya untuk melihat variabel VS dilihat dari perolehan nilai pasda pertanyaan Q5 dan Q6. Persentase nilai untuk pertanyaan Q6 terlihat seperti gambar 12 . 


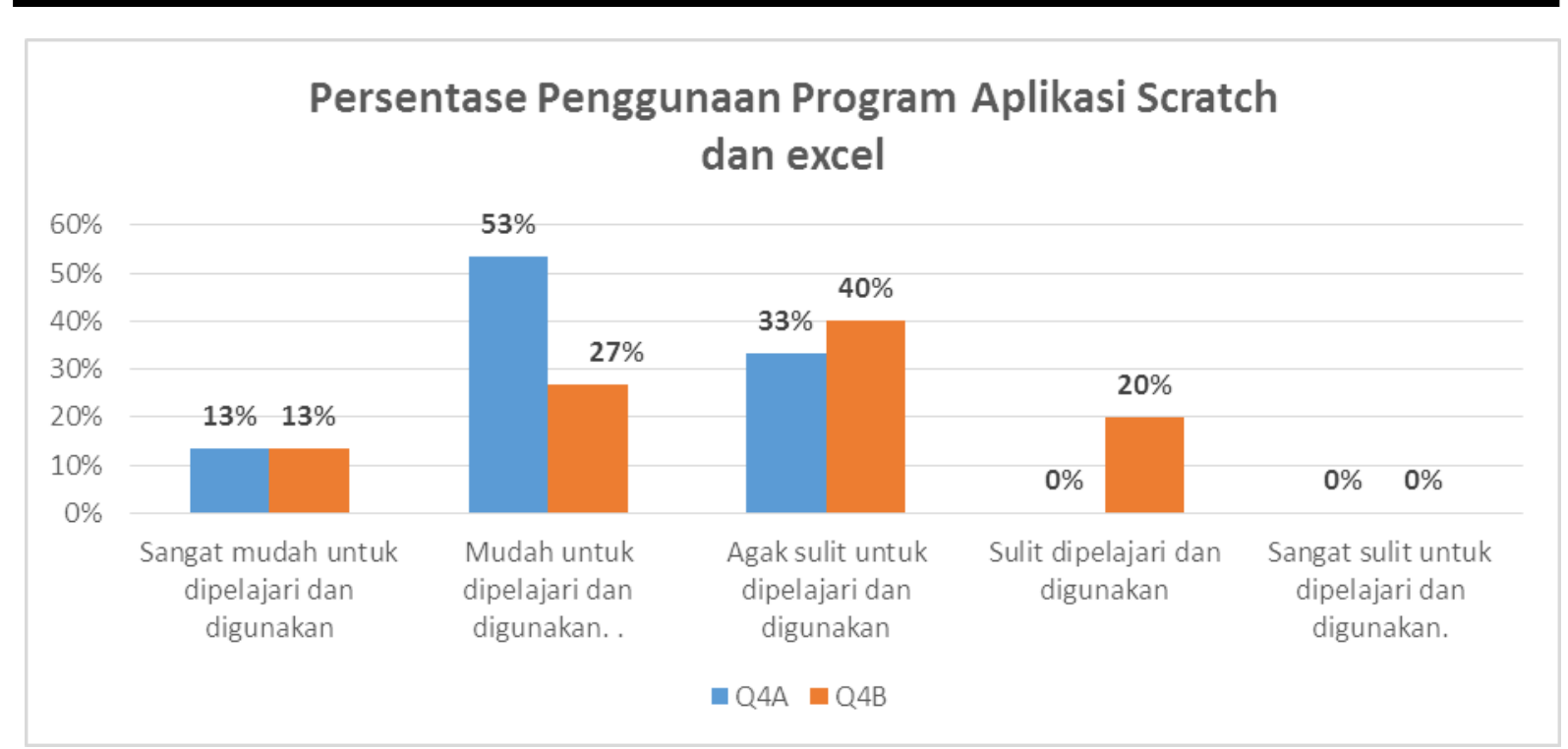

Gambar 11. Grafik Penggunaan Program Aplikasi Scratch Excel

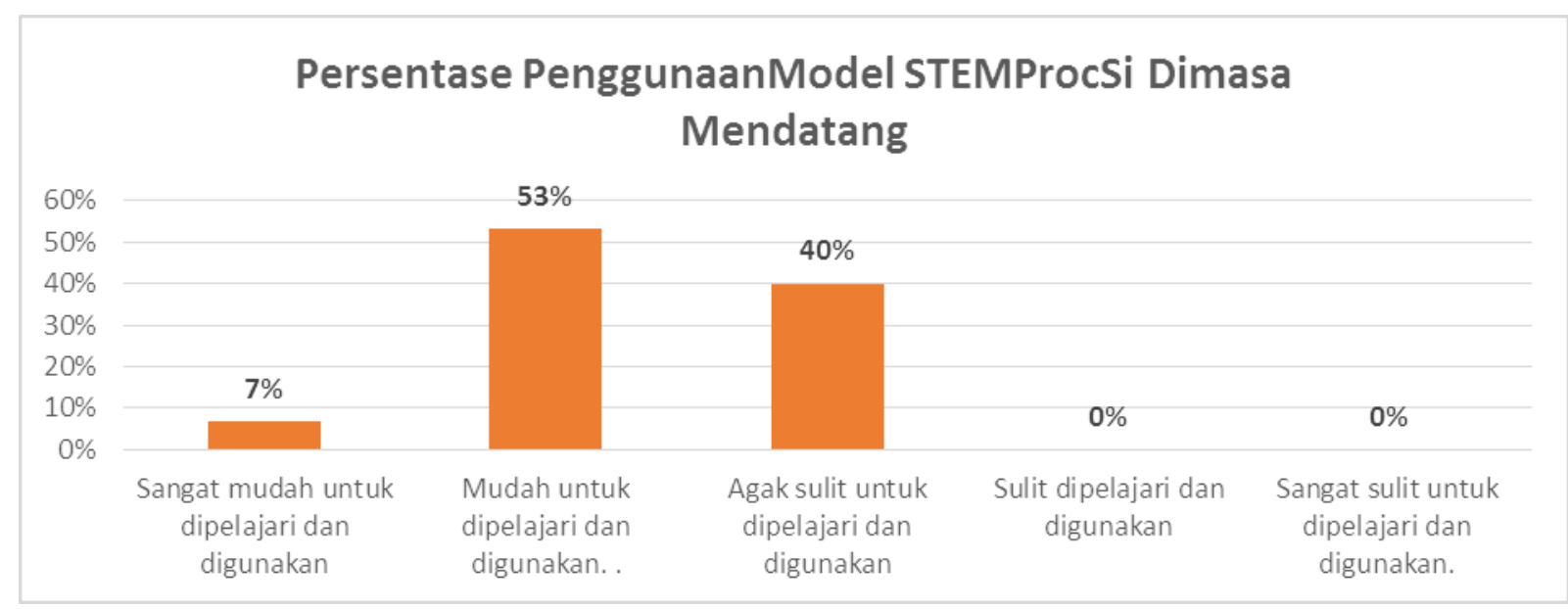

Gambar 12. Persentase Penggunaan Model STEMProcSi dimasa Mendatang

Berdasarkan gambar 12 terlihat bahwa lebih dari separoh mahasiswa berpendapat bahwa model STEMProcSi ini dapat dengan mudah untuk digunakan dan dipelajari, sehingga mahasiswa dapat menggunakan dalam proses pembelajaran. Untuk perolehan nilai rata-rata dari pertanyaan Q6 adalah 3,6 dengan median 4. Hal ini menunjukan bahwa perolehan nilai medianya lebih tinggi dari rata-rata nilai skala liker (3). Untuk pertanyaan Q5 tentang pendapat mahasiswa mengenai pembelajaran dengan model STEMProcSi dapat disimpulkan bahwa sebagin besar dari mahasiswa mengungkapkan pembelajaran dengan model STEMProcSi sangat cocok digunakan di era revolusi industri 4.0, karena pembelajaran terinegragi dengan 4 komponen yatu sain, teknologi, teknik dan matematika. Pengetahuan yang diperoleh langsung diimplementasikan dengan membuat sebuah prosuk yang tercermin dalam kehidupan sehari-hari. Jadi penilaian untuk variabel sikap terlihat bahwa mahasiswa sangat antusias dan tertarik dalam menggunakan model STEMProcSi ini dimasa yang akan datang.

\section{KESIMPULAN}

Hasil dari penelitian menunjukan bahwa model STEMProcSi ini baik untuk digunakan pada mahasiswa PTIK FKIP Universitas Bung Hatta Padang. Model STEMProcSi dapat menumbuhkan minat dan antusias bagi mahasiswa untuk memperoleh pengetahuan, dan dapat membantu mahasiswa dalam melakukan praktek untuk menghasilkan sebuah produk. Selain itu, model ini juga dapat melatih kemampuan komunikasi, kerja sama tim, mengembangkan berpikir kreatif dan berpikir kritis bagi mahasiswa. Hal ini terlihat dari nilai median dari kuisioner adalah 4 yang menunjukan bahwa penilaian mahasiswa terhadap 
model STEMProcSi ini cenderung positif. Dalam pembelajaran dengan model STEMProcsi ini menggunakan 3 program aplikasi sekaligus yaitu XMIND, Excel dan Sratch.

\section{DAfTAR Pustaka}

[1] Klaus, S. 2016. The fourth industrial revolution: what it means, how to respond. Retrieved from https://www. Weforum .org/agenda/2016/01/thefourth-industrial-revolution-what-it-means-andhow-to-respond/

[2] Tsupros, N., Kohler, R., \& Hallinen, J. 2009. STEM education: A project to identify the missing components. Intermediate Unit 1 and Carnegie Mellon. Pennsylvania.

[3] Carter. L. 2017. Neoliberalism and STEM Education: Some Australian Policy Discourse. Canadian Journal of Science, Mathematics and Technology Education. ISSN: 1492-6156 (Print) 1942-4051 (Online) Journal homepage: http://www.tandfonline.com/loi/ucjs20

[4] Krug, D., \& Shaw, A. 2016. Reconceptualizing STEAMS education for teacher education. Canadian Journal of Science, Mathematics and Technology Education, 16(2), 183-200.

[5] Thumlert, K. 2015. Affordances of equality: Ranciere, emerging media and the new amateur. Studies in Art Education, 56(2), 114-126

[6] Young VM, House A, Wang H, et al. 2011. Inclusive STEM schools: early promise in Texas and unanswered questions. Paperpresentedat: NationalResearchCouncilWorkshoponSuccessful STEMEducationinK- 12Schools; Washington, DC.

[7] Bicer A, Navruz B, Capraro RM, et al. 2015. STEM schools vs. non-STEM schools: comparing students'mathematic state based test performance. IJGE. 3(3):8-18.

[8] NavruzB, ErdoganN, BicerA, et al.WouldaSTEMschool'byanyothernamesmellass weet'? Intenational Journal Contemp Education Res.1(2):67-75

[9] Corlu, M.A., \& Corlu, M.S. 2012. The future of undergraduate science mathematics teaching programs. Paper Presented at the International Symposium of Teacher Education Policies and Problems, Ankara, Turkey.

[10] Means. B, HouseA,YoungV, et al. 2013 ExpandingaccesstoSTEM-

focusededucation: whatarethe effects white paper? Symposium presented at: 86th Annual International Conference; RioGrande, PuertoRico.

[11] Ali Bicer, Robert M. Capraro \& Mary M. Capraro, 2017. Hispanic students' mathematics achievement in the context of their high school types as STEM and non-STEM schools,
International Journal of Mathematical Education in Science and Technology.1-16

[12] Cohen, B. 2016. Teaching STEM after school: Correlates of instructional comfort. The Journal of Educational Research.ISSN: 0022-0671 (Print) 1940-0675 (Online) Journal homepage: http://www.tandfonline.com/loi/vjer20

[13] J.F., \& Monagan, M.B. 2007. Teaching mathematics to chemistry students with symbolic computation. Journal of Chemistry Education, 84(2), 889-896.

[14] Walker, E. 2007. "Rethinking Professional Development For Elementary Mathematics Teachers". Journal of Teacher Education Quarterly, 22(1), 113-134.

[15] Langley-Turnbaugh, S.J., Wilson, G., \& Lovewell, L. (2009). Increasing the accessibility of science for all students. Journal of Science Education for Students with Disabilities, 13(1), 1-8.

[16] York, E. 2018. Doing STS in STEM spaces: Experiments in critical participation. Engineering Studies, 10(1), 66-84.

[17] Zeidler, D. L. 2014. "Socioscientific Issues As A Curriculum Emphasis: Theory, Research, And Practice. In NG Lederman \& SK Abell (Eds.)", Handbook of research on science education 2, pp 697-726). Mahwah, NJ: Lawrence Erlbaum Associates.

[18] Zeidler, D. L. 2016. STEM education: A deficit framework for the twenty first century

[19] Yazzie, T., \& Peacock, M. 2018. STEM education and outreach: putting invisible wonders into the spotlight of science education. Salish Sea Ecosystem Conference. British Columbia. University Archives, Heritage Resources, Western Libraries, Western Washington University.

[20] Berlin, D.F., \& White, A.L. 2010. "Preservice Mathematics And Science Teachers In An Integrated Teacher Preparation Program For Grades 7-12: A 3-Year Study Of Attitudes And Perceptions Related To Integration". International Journal of Science and Mathematics Education, 8(1), 97-115.

[21] Sudira, P. 2016.TVET abad XXI filosofi, teori, konsep, dan strategi pembelajaran vokasionaL. Yogyakarta: UNY Press

[22] Button, C.E. 2009. "Towards Carbon Neutrality And Environmental Sustainability At CCSU". International Journal of Sustainability in Higher Education, 10(3), 279-86. 


\section{Biodata Penulis}

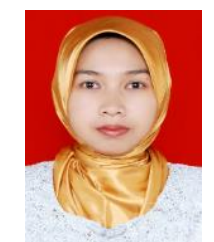

Karmila Suryani lahir pada tanggal 28 April 1982. Gelar Sarjana Sistem Komputer diperoleh Tahun 2005 dari Universitas Putera Indonesia "YPTK" Padang. Tahun 2010 memperoleh gelar Magister Teknologi Informasi di universitas yang sama. Staf pengajar di Program studi Pendidikan Teknologi Informasi dan Komputer di Fakultas Keguruan dan Ilmu Pendidikan Universitas Bung Hatta sejak tahun 2010 sampai sekarang.

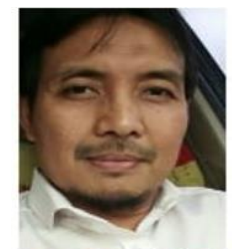

Khairudin, lahir di Pekan Baru pada tanggal 2 Februari 1967. Lulus dengan gelar Sarjana Sains jurusan Matematika di Universitas Riau pada tahun 1993. Memperoleh gelar Magister Sains di Universitas Gadjah Mada (UGM) Yogyakarta pada tahun 2004. 